\title{
Natural (ghrelin) and synthetic (hexarelin) GH secretagogues stimulate H9c2 cardiomyocyte cell proliferation
}

\author{
I Pettersson, G Muccioli ${ }^{1}$, R Granata ${ }^{2}$, R Deghenghi ${ }^{3}$, E Ghigo ${ }^{2}$, \\ C Ohlsson and J Isgaard
}

Research Center for Endocrinology and Metabolism, Department of Internal Medicine, Gröna Stråket 8, Sahlgrenska University Hospital, SE-413 45 Göteborg, Sweden

${ }^{1}$ Department of Anatomy, Pharmacology and Forensic Medicine, University of Turin, Turin, Italy

${ }^{2}$ Department of Internal Medicine, University of Turin, Turin, Italy

${ }^{3}$ Europeptides, Argenteuil, France

(Requests for offprints should be addressed to J Isgaard; Email: jorgen.isgaard@medic.gu.se)

\begin{abstract}
Recent experimental data demonstrate cardiovascular effects of the GH secretagogues (GHSs) hexarelin and ghrelin, the proposed natural ligand for the GHS receptor. Moreover, specific cardiac binding sites for GHSs have been suggested. The aim of the present study was to investigate if the natural ligand ghrelin and synthetic GHS peptide hexarelin and analogues have direct effects on the cardiomyocyte cell line, H9c2. Hexarelin stimulated thymidine incorporation in a dose-dependent manner with significant responses at $3 \mu \mathrm{M} \quad(147 \pm 3 \%$ of control, $P<0 \cdot 01)$ and elicited maximal effects at concentrations around $30 \mu \mathrm{M}$. This activity was seen already after $12 \mathrm{~h}$ of incubation with a maximal effect after $18 \mathrm{~h}(176 \pm 9 \%$ of control, $P<0 \cdot 01)$. Ghrelin also had a significant stimulatory effect on thymidine incorporation $(129 \pm 2 \%$ of control at $3 \mu \mathrm{M}$ and $18 \mathrm{~h}, P<0 \cdot 05)$. The stimulatory effect on thymidine incorporation of hexarelin, Tyr-Ala-hexarelin, EP80317 and ghrelin was specific and no stimulatory
\end{abstract}

effect was observed with the truncated GH-releasing peptide EP51389 or the non-peptidyl GHS MK-0677. In competitive binding studies, ${ }^{125}$ I-labeled Tyr-Alahexarelin was used as radioligand and competition curves showed displacement with hexarelin, Tyr-Ala-hexarelin, EP80317 and ghrelin, whereas MK-0677 and EP51389 produced very little displacement at $1 \mu \mathrm{M}$ concentration, adding further support for an alternative subtype binding site in the heart compared with the pituitary. In conclusion, we have demonstrated a dose-dependent and specific stimulation of cardiomyocyte thymidine incorporation by natural and synthetic GHS analogues, suggesting increased cell proliferation and binding of GHS to H9c2 cardiomyocyte cell membranes. These findings support potential peripheral effects of GHS on the cardiovascular system independent of an increased GH secretion.

Journal of Endocrinology (2002) 175, 201-209

\section{Introduction}

The growing family of synthetic growth hormone (GH) secretagogues (GHSs) (Camanni et al. 1998) consists of peptides and non-peptides structurally derived from metenkephalin and synthesized by Bowers and collaborators in the early 1980s (Momany et al. 1981, Bowers 1998). Since the peptidyl GHSs have very low oral bioavailability and short half-lives, several small non-peptidyl molecules have been designed which are less susceptible to degradation and have higher bioavailability. The spiroindolin derivative MK-0677 is a small non-peptidyl GHS with excellent oral bioavailability (Smith et al. 1997). Using MK-0677 as a ligand, a receptor in membranes isolated from pituitary and hypothalamic tissue was identified and it was suggested to be a G-protein coupled receptor (Pong et al. 1996). Subsequently, the receptor was cloned from porcine, human and rat pituitary tissue (Howard et al. 1996, McKee et al. 1997a) and revealed no similarities to any other known G-protein coupled receptor. The receptor showed 96\% homology between rat and human, and studies on the pufferfish have shown that it has been conserved for at least 400 million years (Palyha et al. 2000). Recent studies have demonstrated other subtypes of the receptor, which are expressed also in peripheral tissues (McKee et al. 1997b, Tan et al. 1998). Specific binding sites for GHSs have been found in thyroid (Cassoni et al. 2000) and cardiac (Ong et al. 1998a, Bodart et al. 1999, 2002, Papotti et al. 2000) tissue.

Recently, an endogenous ligand for the GHS receptor (GHS-R) was identified in rat stomach and designated ghrelin (Kojima et al. 1999). This ligand was found to have 
no structural homology with any of the synthetic GHSs and the existence of an $n$-octanoyl group at the Ser3 residue seemed to be necessary for the GH-releasing activity. The plasma concentration of active noctanoylated ghrelin is around $4 \mathrm{pM}$ and the total amount (both active and inactive form) is around $200 \mathrm{pM}$ in rats (Hosoda et al. 2000b). The circulating level of total ghrelin is also around $200 \mathrm{pM}$ in the human (Ariyasu et al. 2001). Ghrelin has been shown to have a very short half-life (Tschöp et al. 2000), suggesting the importance of rapid changes of the plasma concentration.

The most prominent and well-characterized effect of GHSs is the ability to release GH both in vivo and in vitro and it has been suggested that they act at both the pituitary and the hypothalamic level (Bowers et al. 1984, Dickson et al. 1993, Shimon et al. 1998). More recently, the GHSs have also been proposed to have peripheral effects. Hexarelin, which is a 2-methyl $\mathrm{D}$-Trp derivative of $\mathrm{GH}$ releasing peptide-6 (GHRP-6) (His-D-Trp-Ala-Trp-DPhe-Lys- $\mathrm{NH}_{2}$ ) (Deghenghi et al. 1994, Ghigo et al. 1994), has been shown to improve cardiac function in rats after experimental myocardial infarction (Tivesten et al. 2000) and to be protective against postischemic dysfunction of perfused hearts isolated from GH-deficient (De Gennaro Colonna et al. 1997), senescent (Rossoni et al. 1998) and hypophysectomized (Locatelli et al. 1999) rats. Moreover, when hexarelin was injected i.v in a single dose to hypopituitary adult patients, a significant increase in left ventricular ejection fraction was observed, suggesting a GH-independent inotropic effect (Bisi et al. 1999). Ghrelin has been shown to acutely decrease systemic vascular resistance in $\mathrm{GH}$-deficient rats, suggesting that ghrelin also has a GH/insulin-like growth factor (IGF-I)-independent vasodilatory effect (Nagaya et al. 2001b).

Specific binding to rat cardiac membranes has been suggested using an iodinated and photoactivatable derivative of hexarelin, ${ }^{125}$ I-labeled Tyr-Bpa-Ala-hexarelin (Ong et al. 1998a, Bodart et al. 1999). Papotti et al. (2000) have also shown specific binding to human cardiac tissue using iodinated Tyr-Ala-hexarelin. Binding of hexarelin to H9c2 cells has previously been shown (Filigheddu et al. 2001); however, to the best of our knowledge no studies demonstrating direct effects of GHS and also binding of ghrelin to cardiomyocytes have yet been published.

The H9c2 cardiomyocyte cell line (Kimes \& Brandt 1976) is derived from embryonic rat ventricle and shows both cardiac and skeletal muscle cell properties (Kimes \& Brandt 1976, Hescheler et al. 1991). It has been used in several studies to investigate different cellular mechanisms in cardiomyocytes (Sipido \& Marban 1991, Wu et al. 1996, Chen et al. 2000) and has been shown to be responsive to IGF-I (Chen et al. 1995, Bahr et al. 1997).

The aim of the present study was to investigate possible direct effects of hexarelin and ghrelin on H9c2 cells. Moreover, iodinated Tyr-Ala-hexarelin was used to show specific binding to a GHS-R in H9c2 cells.

\section{Materials and Methods}

\section{Peptides}

Hexarelin, recombinant human GH and IGF-I (lot 1009, $4100 \mathrm{U} / \mathrm{mg}$ ) were from Pharmacia \& Upjohn (Stockholm, Sweden) and the GHS, Tyr-Ala-hexarelin, EP51389, EP80317 and MK-0677 were all provided by Europeptides (Argenteuil, France). The rat ghrelin came from Neosystem (Strasbourg, France) The GHS EP80317 (Haic-D-2-Me-Trp-D-Lys-Trp-D-Phe-Lys- $\mathrm{NH}_{2}$ ) is a hexapeptide with a primary structure similar to the hexapeptide hexarelin (His-D-2 Me-Trp-Ala-Trp-D-PheLys- $\mathrm{NH}_{2}$ ), although EP80317 is characterized by a D-Lys in the third position, which has been previously suggested to be of importance for blunting of the GH-releasing property (Momany et al. 1981). Somatostatin-14 (SRIF14) was purchased from Bachem Feinchemikalien AG (Bubendorf, Switzerland). The iodination of Tyr-Alahexarelin with ${ }^{125} \mathrm{I}$ (specific activity $2200 \mathrm{Ci} / \mathrm{mmol}$ ) was performed by EuroDiagnostica AB (Malmö, Sweden), using the chloramine- $\mathrm{T}$ method followed by purification on a $\mu$-Bondapak $\mathrm{C}_{18}$ column (Sweden Waters $\mathrm{AB}$, Sollentuna, Sweden).

\section{Cell culture}

H9c2 cardiac muscle cell line was obtained from American Type Culture Collection (Manassas, VA, USA) at passage 14 and cultured in DMEM complete culture medium (DMEM/F12 supplemented with 10\% fetal calf serum (FCS), $2 \mathrm{mM}$ L-glutamine, $0.5 \mathrm{mg} / 1$ Fungizone and $50 \mathrm{mg} / 1$ gentamicin). Experiments were performed at passage 19-25. The stock of cells used for experiments were sub-cultured 1:5 twice a week. Cells used for thymidine incorporation were seeded in triplicates in six-well plates at $4 \times 10^{3}$ cells $/ \mathrm{cm}^{2}$, cultured for 2 days, washed twice with $2 \mathrm{ml}$ DMEM and starved for $24 \mathrm{~h}$ in DMEM starvation medium (DMEM/F12 supplemented with $0.5 \%$ BSA, $2 \mathrm{mM}$ L-glutamine, $0.5 \mathrm{mg} / 1$ Fungizone and $50 \mathrm{mg} / 1$ gentamicin). After the starvation the cells were washed once with DMEM and used for GHS stimulation. DMEM/F12, L-glutamine, Fungizone, Hepes and Dulbecco's PBS were all from Gibco BRL and FCS was from Harlan Seralab Ltd (Loughborough, UK). BSA came from Sigma Chemical Company (St Louis, MO, USA). Gentamicin was purchased from Seromed (Berlin, Germany). The cell culture bottles and plates came from Costar (High Wycombe, Bucks, UK).

\section{Thymidine incorporation}

The cells were incubated for $18 \mathrm{~h}$ at $37^{\circ} \mathrm{C}$ with various concentrations of GHS, or for various lengths of time with $10 \mu \mathrm{M}$ GHS in starvation medium. As vehicle control, wells with only starvation medium were used. During the 
last $60 \mathrm{~min}, 1 \mu \mathrm{Ci}\left[\right.$ methyl- $\left.{ }^{3} \mathrm{H}\right]$ thymidine (Amersham Pharmacia Biotech) per $\mathrm{ml}$ was added. The cells were washed three times with $3 \mathrm{ml}$ ice-cold Dulbecco's PBS (containing $\mathrm{Ca}^{2+}$ and $\mathrm{Mg}^{2+}$ ) and solubilized with $500 \mu \mathrm{l}$ $10 \%$ SDS at room temperature. DNA was precipitated with $500 \mu \mathrm{l}$ ice-cold $20 \%$ trichloroacetic acid (TCA) and collected on Whatman GF/C glass fiber filters. The precipitate was washed twice with ice-cold 10\% TCA and twice with ice-cold 95\% ethanol. The radioactivity associated with the filters was quantified using liquid scintillation (Beta counter; Beckman LS6500, High Wycombe, Bucks, UK). The c.p.m. data from each time point were corrected against the vehicle control, which was set to $100 \%$ thymidine incorporation. The results for the different GHSs in various concentrations are presented as percent of control. This is done separately for each thymidine incorporation experiment performed.

\section{Membrane preparation}

The membrane preparation and binding protocol used was a slight modification of the one used by Muccioli et al. (1998). H9c2 cells were cultured in $162 \mathrm{~cm}^{2}$ flasks and harvested at confluency. The cells were washed once in PBS (without $\mathrm{Mg}^{2+}$ or $\mathrm{Ca}^{2+}$ ) and scraped off with a rubber policeman in $0 \cdot 34 \mathrm{M}$ sucrose. They were homogenized with a Dounce homogenizer in $50 \mathrm{mM}$ Tris- $-\mathrm{HCl}$ buffer also containing 2.5 mM EGTA, 0.34 M sucrose and protease inhibitors, $\mathrm{pH} 7 \cdot 4$. After homogenization they were centrifuged at $30000 \mathrm{~g}$ for $30 \mathrm{~min}$ at $+4{ }^{\circ} \mathrm{C}$. The pellet was resuspended and homogenized in ice-cold resuspension buffer (50 mM Tris-HCl, $2.5 \mathrm{mM}$ EGTA, $0.003 \%$ bacitracin). The protein concentration was determined using a Bio Rad DC Protein Assay kit.

\section{Receptor binding assay}

Tyr-Ala-hexarelin have been reported to have the same GH-releasing activity as hexarelin in rats (Ong et al. 1998a) and ${ }^{125}$ I-labeled Tyr-Ala-hexarelin has been used in other studies to show GHS-R binding (Muccioli et al. 1998, Cassoni et al. 2000, Papotti et al. 2000). To show binding-site specificity, different GHSs, natural (ghrelin) and synthetic (hexarelin, Tyr-Ala-hexarelin, as well as two different hexarelin analogues, EP80317 and EP51389, MK-0677) and the neuropeptide SRIF-14 were used as competitors in a displacement assay. The concentration of the competitors ranged from $1 \mathrm{nM}$ to $10 \mu \mathrm{M}$. Nonspecific binding was calculated as binding which was not displaced by $1 \mu \mathrm{M}$ unlabeled Tyr-Ala-hexarelin. The data are presented as a percent of specific binding in the absence of unlabeled competitor.

Approximately $100 \mu \mathrm{g}$ of membrane protein were incubated in triplicate at $0{ }^{\circ} \mathrm{C}$ for $60 \mathrm{~min}$ together with $1.5 \mathrm{nM}$ radioligand and different concentrations of competitor in assay buffer (50 mM Tris- $\mathrm{HCl}, 2.5 \mathrm{mM}$ EGTA,
$0 \cdot 1 \%$ BSA, $0 \cdot 003 \%$ bacitracin). The final volume was $0.5 \mathrm{ml}$. The binding reaction was terminated by adding $4 \mathrm{ml}$ assay buffer followed by filtration over Whatman GF/B filters presoaked for $60 \mathrm{~min}$ in $0.5 \%$ polyethyleneimine to minimize non-specific binding of the radioligand to the filters. Filters were rinsed three times with assay buffer and the bound radioactivity measured in an LKB 1260 gamma counter (Wallac, Turku, Finland). The dissociation constant $\left(K_{\mathrm{d}}\right)$ and the number of binding sites $\left(\mathrm{B}_{\max }\right)$ were calculated from a saturation curve (Fig. 4) using non-linear regression and the GraphPad Prism 3 program (GraphPad, San Diego, CA, USA). The radioligand competition curves were also analyzed with the GraphPad program and $\mathrm{IC}_{50}$ values for the various GHSs were calculated.

\section{RT-PCR for GHS-R1a}

Total RNA extraction from frozen rat hypothalamus and from the H9c2 cell line was performed using TRIzol (Life Technologies, S Giuliano Milanese, Italy) according to the modified single-step RNA isolation method of Chomzynski \& Sacchi (1987). The reverse transcriptase reaction was performed using $3 \mu \mathrm{g}$ total RNA with Moloney murine leukemia virus reverse transcriptase (PE Applied Biosystems, Foster City, CA, USA) under the conditions recommended by the supplier. The forward and reverse primer sequences (TIB Molbiol, Genova, Italy) for rat GHS-R1a were 5'-GTCGAGCGCTAC TTCGC-3' and 5'-GTACTGGCTGATCTGAGC-3' respectively (Yokote et al. 1998). The GHS-R primers were located on different exons. The primers for $\beta$-actin were $\quad 5^{\prime}$-GGTCATCTTCTCGCGGTTGGCCTTGG GGT-3' (forward) and 5'-CCCCAGGCACCAGGGCG TGAT-3' (reverse). After an initial denaturation step ( $94^{\circ} \mathrm{C}$ for $10 \mathrm{~min}$ ), 32 cycles of PCR were carried out in a $50 \mu \mathrm{l}$ volume with AmpliTaq Gold Polymerase (PE Applied Biosystems) in a GeneAmp PCR System 9600 (PE Applied Biosystems) under the following conditions: one cycle, $94{ }^{\circ} \mathrm{C}$ for $30 \mathrm{~s}, 55^{\circ} \mathrm{C}$ for $30 \mathrm{~s}, 72{ }^{\circ} \mathrm{C}$ for $30 \mathrm{~s}$; $72{ }^{\circ} \mathrm{C}$ for $10 \mathrm{~min}$ for elongation. The PCR products (492 bp for GHS-R1a and $230 \mathrm{bp}$ for $\beta$-actin) were electrophoresed in $1.5 \%$ agarose gel and visualized by ethidium bromide staining.

\section{Statistical analysis}

Data are presented as means \pm S.E.M. unless otherwise stated. The statistical significance was tested using Student's $t$-test.

\section{Results}

Stimulatory effects of hexarelin and ghrelin on $\mathrm{H} 9 \mathrm{c} 2$ cells

A time course study of hexarelin $(10 \mu \mathrm{M})$ showed significant effects on thymidine incorporation already after $12 \mathrm{~h}$ 


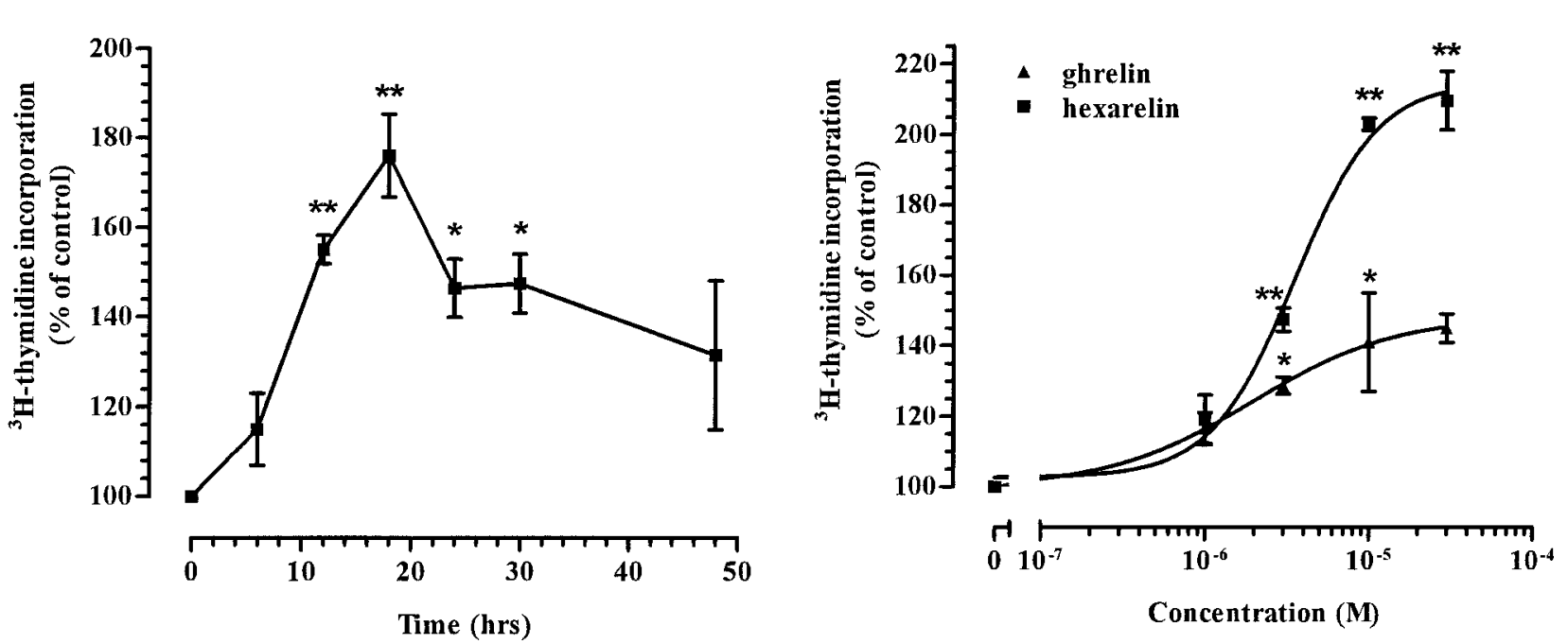

Figure 1 Time-course effect of hexarelin on $\left[{ }^{3} \mathrm{H}\right]$ thymidine incorporation in $\mathrm{H} 9 \mathrm{c} 2$ cells. Cells were incubated with $10 \mu \mathrm{M}$ hexarelin. After the indicated length of time the cells were harvested and the radioactivity was measured. The data were corrected against the basal vehicle background level and the c.p.m. from each time point is shown as a percent of vehicle control \pm S.E.M. and represents results from three separate experiments in triplicate. ${ }^{*} P<0 \cdot 01,{ }^{\star} P<0 \cdot 05$ vs vehicle control.

$(155 \pm 3 \%$ of control, $P<0 \cdot 01)$ and maximal effects after $18 \mathrm{~h}(176 \pm 9 \%$ of control, $P<0 \cdot 01)$; thereafter it decreased (Fig. 1). The stimulatory effect on thymidine incorporation was dose-dependent for both hexarelin and ghrelin with significant responses at $3 \mu \mathrm{M}(147 \pm 3 \%$ of control $(P<0 \cdot 01)$ and $129 \pm 2 \%$ of control $(P<0 \cdot 05)$ respectively $)$. Maximal effects with hexarelin were obtained using concentrations around $30 \mu \mathrm{M}(210 \pm 8 \%$ of control, $P<0 \cdot 01)$ (Fig. 2).

\section{Specificity of the stimulatory effect}

To study the specificity of GHSs on stimulating H9c2 cells, we also incubated cells with EP51389, a truncated GHRP derivative with strong GH-releasing activity (Bodart et al. 1999, Locatelli et al. 1999), EP80317, a GHRP antagonist which does not release GH but has a strong affinity to the pituitary/hypothalamus GHS-R (Muccioli et al. 2001) and MK-0677, a non-peptidyl GHS (Smith et al. 1997).

We found an effect on thymidine incorporation in H9c2 cells with hexarelin and ghrelin (Fig. 2). Moreover, both Tyr-Ala-hexarelin and EP80317 also had a stimulatory effect on thymidine incorporation but neither the small non-peptidyl GHS, MK-0677, nor the truncated GHRP derivative, EP51389, showed that stimulatory effect. In fact both MK-0677 and EP51389 had a negative impact on thymidine incorporation, which resulted in thymidine incorporation being lower than in the control (Fig. 3). When hexarelin and MK-0677 were combined $(1+1)$ at

Figure 2 Dose-response effect of hexarelin and rat ghrelin on $\left[{ }^{3} \mathrm{H}\right]$ thymidine incorporation in $\mathrm{H} 9 \mathrm{c} 2$ cells. Cells were incubated with indicated concentrations of GHSs. After $18 \mathrm{~h}$ the cells were harvested and the radioactivity was measured. The c.p.m. data, which are corrected against the vehicle control, are presented as percent of controls \pm S.E.M. and represent results from three separate experiments in triplicate, except for the highest ghrelin concentration $(30 \mu \mathrm{M})$, which represents three wells from one experiment. Data were fitted by non-linear regression analysis. ${ }^{*} P<0 \cdot 01,{ }^{*} P<0 \cdot 05$ vs vehicle control.

$10 \mu \mathrm{M}$ the stimulatory effect of hexarelin on thymidine incorporation was completely attenuated and was even lower than for the vehicle control. The tendency was the same when EP51389 was combined with hexarelin, but

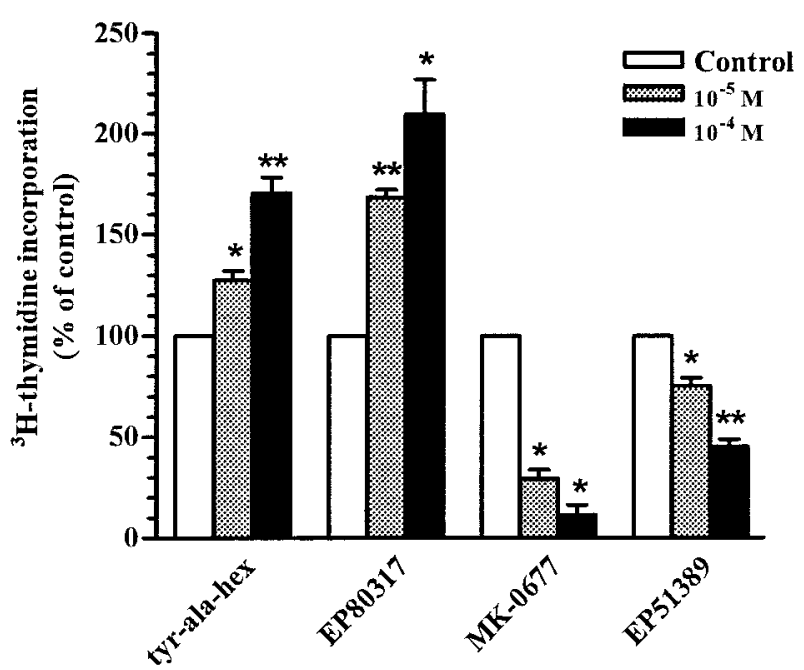

Figure 3 Specificity of the GHS effect of on $\mathrm{H} 9 \mathrm{c} 2$ cells. Cells were incubated with two different concentrations (10 and $100 \mu \mathrm{M})$ of each GHS. After $18 \mathrm{~h}$ the cells were harvested and the radioactivity was measured. The c.p.m. data, which are corrected against the vehicle control, are presented as percent of controls \pm S.E.M. and represent results from three separate experiments in triplicate. ${ }^{* *} P<0 \cdot 01,{ }^{\star} P<0 \cdot 05$ vs vehicle control. 


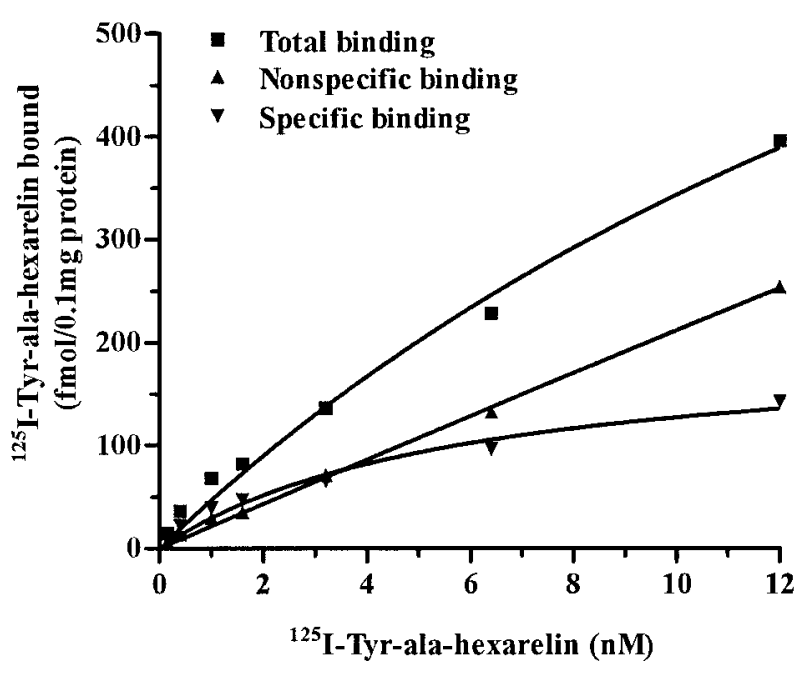

Figure 4 Saturation curve of ${ }^{125}$ I-labeled Tyr-Ala-hexarelin binding to $\mathrm{H} 9 \mathrm{c} 2$ cell membranes. A fixed amount of membrane protein (100 $\mu \mathrm{g} /$ tube) was incubated with increasing concentrations of radiolabeled Tyr-Ala-hexarelin alone (total binding) or plus $10 \mu \mathrm{M}$ of unlabeled Tyr-Ala-hexarelin to define non-specific binding. Specific binding values were obtained by subtracting non-specific binding from total binding. Data in the Figure are from one representative experiment.

here $10 \mu \mathrm{M}$ GHS did not manage to show significant inhibition of the hexarelin effect on the thymidine incorporation (data not shown).

As positive control, we also performed experiments with IGF-I incubation with $\mathrm{H} 9 \mathrm{c} 2$ cells in a concentration of $10 \mu \mathrm{M}$, showing a stimulation of thymidine incorporation of $147 \pm 7 \%$ of control $(P<0 \cdot 001)$. GH was not able to stimulate thymidine incorporation in the $\mathrm{H} 9 \mathrm{c} 2$ cells (data not shown).

\section{Receptor-binding studies}

H9c2 cell membranes were used for the binding studies and the specific binding of ${ }^{125}$ I-labeled Tyr-Ala-hexarelin was calculated as the difference between binding in the absence (total binding) and in the presence of $10 \mu \mathrm{M}$ unlabeled Tyr-Ala-hexarelin (non-specific binding). Experiments using increasing concentrations of ${ }^{125} \mathrm{I}-$ labeled Tyr-Ala-hexarelin revealed the presence of a saturable specific binding associated with a high nonspecific binding that linearly increased as a function of the radioligand concentrations (Fig. 4). Scatchard analysis of the specific binding data (Figure not shown) demonstrated the existence of a single class of binding sites with a $K_{\mathrm{d}}$ of $7 \cdot 5 \pm 1 \cdot 0 \mathrm{nM}$ and $\mathrm{a} \mathrm{B}_{\max }$ of $2023 \pm 168 \mathrm{fmol} / \mathrm{mg}$ of protein (means \pm S.E.M. of three separate experiments). The specificity of ${ }^{125}$ I-labeled Tyr-Ala-hexarelin binding to $\mathrm{H} 9 \mathrm{c} 2$ membranes was established by determining the ability of different compounds to compete with the radioligand for binding sites. Based on saturation binding

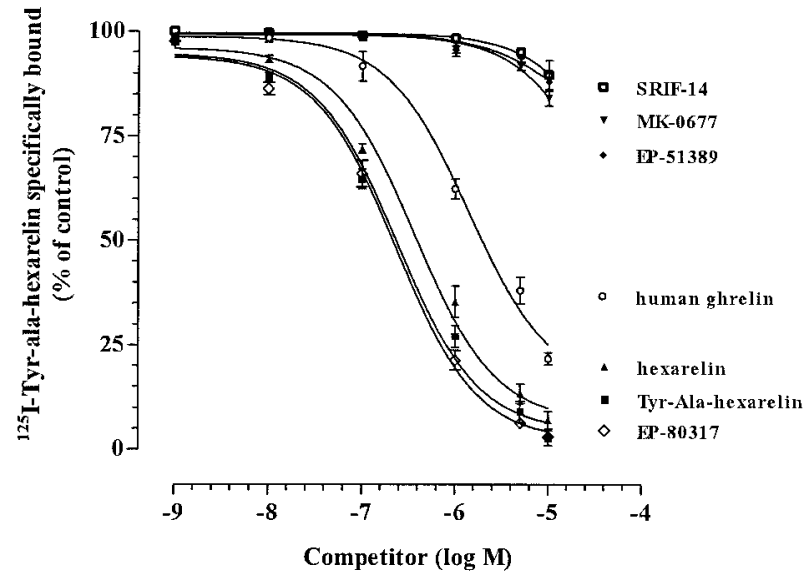

Figure 5 Competition curves using ${ }^{125}$-labeled Tyr-Ala-hexarelin as radioligand and several different unlabeled substances as competitors. The ordinate represents specific binding as percentage of control (i.e. specific binding in the absence of unlabeled competitor). Data in the Figure are from one representative experiment.

data, competition was performed at a radioligand concentration $(1.5 \mathrm{nM})$ where the specific binding value (about $58 \%$ of total radioactivity bound) was greater than that of non-specific binding. Figure 5 shows that Tyr-Alahexarelin, hexarelin, EP80317 and human ghrelin displaced the radioligand Tyr-Ala-hexarelin from binding sites in a dose-dependent manner. The $\mathrm{IC}_{50}$ values (means \pm S.E.M. of three separate experiments, all expressed as $\mu \mathrm{M})$ were $0 \cdot 25 \pm 0.04$ for Tyr-Ala-hexarelin, $0 \cdot 39 \pm 0.07$ for hexarelin, $0 \cdot 2 \pm 0 \cdot 05$ for EP80317 and $1 \cdot 4 \pm 0 \cdot 19$ for ghrelin. In contrast, no or little competition was observed in the presence of other competitors such as MK-0677, EP51389 or SRIF-14.

\section{GHS-R expression}

To study possible expression of the GHS-R, amplification of GHS-R1a mRNA by RT-PCR was performed in the H9c2 cells (Fig. 6). Rat hypothalamus was used as positive control showing a $492 \mathrm{bp}$ target band. Buffer alone was used as negative control. As can be seen in Fig. 6, H9c2 cells do not express detected levels of GHS-R1a mRNA.

\section{Discussion}

The main findings of the present study were that hexarelin shows binding to $\mathrm{H} 9 \mathrm{c} 2$ cardiomyocytes and stimulates thymidine incorporation in a dose-dependent and specific manner. A stimulatory effect on cell proliferation was also observed after incubation with ghrelin, the proposed endogenous ligand for the GHS-R.

To the best of our knowledge this is the first study showing direct stimulatory effects of synthetic GHSs and 


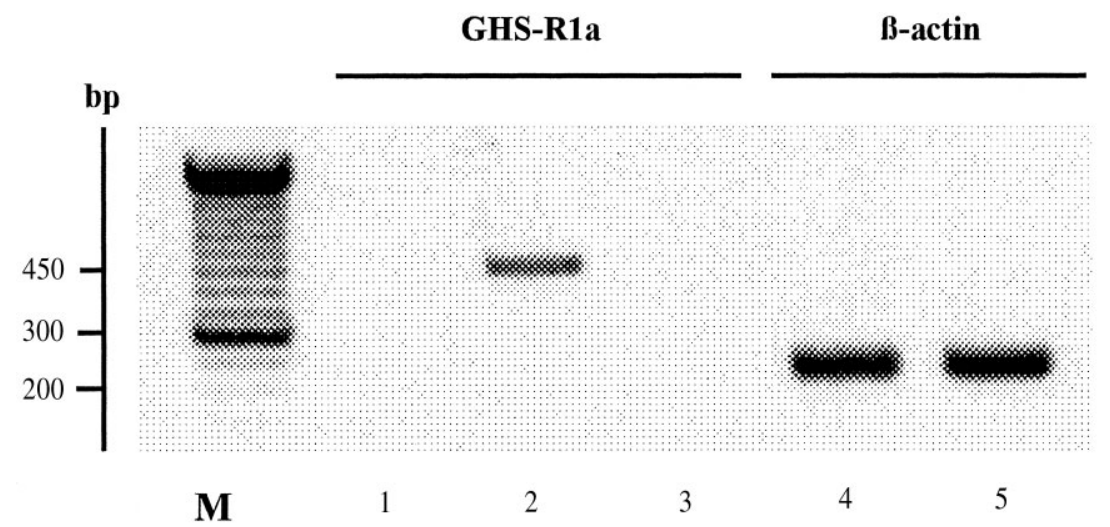

Figure 6 Amplification of GHS-R1a mRNA by RT-PCR in H9c2 rat heart derived cell line. $\mathrm{H}$ 9c2 cells were cultured in medium (DMEM) containing 10\% fetal bovine serum for $24 \mathrm{~h}$. Three micrograms of isolated total RNA were reverse transcribed and one-quarter of the total cDNA was used for PCR with specific GHS-R1a and $\beta$-actin primers. The PCR products were separated by agarose gel (1.5\%) electrophoresis and visualized with ethidium bromide. The amplified products for GHS-R1a and for $\beta$-actin were 492 and $230 \mathrm{bp}$ respectively. M, 50 bp ladder. Buffer alone was used as negative control (lane 1) and rat hypothalamus as positive control (lane 2). As shown in lane 3, H9c2 cells do not express detected levels of GHS-R1a mRNA. $\beta$-Actin was used as an internal control for equivalent amounts of amplified samples (lane 4 for hypothalamus and 5 for H9c2). Shown is a representative RT-PCR from three separate experiments performed on three different RNA samples.

ghrelin on cardiomyocyte-like cells. Direct and GHindependent effects of GHSs on the cardiovascular system have previously been suggested and they include improvement of systolic function in rats after experimental infarction (Tivesten et al. 2000), cardioprotection against postischemic dysfunction in perfused rat hearts (De Gennaro Colonna et al. 1997, Rossoni et al. 1998) and increase of left ventricular ejection fraction in hypopituitary patients (Bisi et al. 1999). In a recent study Nagaya et al. (2001b) reported data of a decrease in systemic vascular resistance in GH-deficient rat treated with a single injection of ghrelins, suggesting that ghrelin has GH/IGF-1-independent vasodilatory effects.

However, at present no conclusive data demonstrating cardiac effects of GHS on the cellular level have been reported. In the present study, a dose-dependent effect of hexarelin and ghrelin was observed with a significant effect at $3 \mu \mathrm{M}$ and a maximal effect for hexarelin at concentrations around $30 \mu \mathrm{M}$. This is comparable to previously reported concentrations needed to stimulate a dose-dependent increase in coronary perfusion pressure when hexarelin is administered to rat hearts in a Langendorff perfusion system (Bodart et al. 1999). The plasma concentration of ghrelin in both the human (Ariyasu et al. 2001) and rat (Hosoda et al. 2000b) is around $0.2 \mathrm{nM}$ and a single injection of $10 \mu \mathrm{g} / \mathrm{kg}$ to healthy males resulted in a marked decrease in systemic vascular resistance (Nagaya et al. 2001a). The plasma concentration was $45 \mathrm{nM}$ after $1 \mathrm{~min}$ and decreased to $4.5 \mathrm{nM}$ after $100 \mathrm{~min}$, with a remaining effect on vascular resistance. The ghrelin concentrations for these effects are lower than the concentrations that were needed to obtain thymidine incorporation effects in vitro. However, in vitro studies are difficult to compare with in vivo experiments since culturing conditions may influence the concentration needed for an effect. Also, since GHS-R expression has been shown in the whole heart and in the aorta (Nagaya et al. 2001a) these hemodynamic effects may very well be mediated through the cloned GHS-R and our effects through another different GHS subtype receptor.

In order to test the specificity of the proliferative effect on H9c2 cells, several GHRPs and MK-0677, a nonpeptidyl GHS, were tested in two different concentrations: 10 and $100 \mu \mathrm{M}$. Interestingly, no stimulatory effect of MK-0677 was observed, suggesting that the effect on thymidine incorporation may be specific for peptidyl GHS. Moreover, a truncated GHRP, EP51389, was also ineffective in binding to and stimulating $\mathrm{H} 9 \mathrm{c} 2$ thymidine incorporation. These findings are in agreement with Bodart et al. (1999), who also reported a lack of effect on coronary perfusion pressure by MK-0677 and EP51389. In our study, both MK-0677 and EP51389 had a negative effect on thymidine incorporation, resulting in decreased values compared with controls. MK-0677 was able to completely blunt the effect of hexarelin when the cells were co-incubated with both agents. In contrast, EP51389 was only able to partially inhibit the stimulatory effect of hexarelin on thymidine incorporation. The reason for this inhibitory effect and possible differences in the mechanism 
of action of these compounds are unclear and need to be further studied.

The modified hexarelin, Tyr-Ala-hexarelin, that was used for ${ }^{125} \mathrm{I}$ iodination was found to be effective in stimulating thymidine incorporation. Another peptide, EP80317, which has a structure similar to hexarelin and binds to the GHS-R (Muccioli et al. 2001) but is characterized by a D-Lys in the third position, which previously has been suggested to have a negative impact on GH release from the pituitary (Momany et al. 1981), was also found to have a dose-dependent stimulatory effect on thymidine incorporation.

Overall, the results indicate specificity of the stimulatory effect on thymidine incorporation by peptidyl GHS and ghrelin and are in agreement with the hypothesis that a different subtype of the GHS-R found in the pituitary is present in cardiomyocytes. This proposed novel cardiac receptor seems to bind full-length GHRP-6 derivatives such as hexarelin, Tyr-Ala-hexarelin, EP80317 and also ghrelin, but not the non-peptidyl GHS MK-0677 or the truncated GHRP, EP51389. The GHS-R was cloned from its ability to bind MK-0677 (Howard et al. 1996) and has been found to be expressed in whole heart tissue (Nagaya et al. 2001a). However, whether it is expressed in cardiomyocytes or in other cell types in the heart remains to be investigated. We were not able to show binding of MK-0677 or expression of the GHS-R in H9c2 cardiac cells. The positive effect we found on thymidine incorporation seems to be separate from the GH-releasing effect of GHS and suggests a subtype receptor that is expressed in cardiomyocytes.

To date two different suggested endogenous ligands for the GHS-R have been isolated and characterized from rat stomach, the 28 amino acid peptide ghrelin (Kojima et al. 1999) and des-Gln ${ }^{14}$-ghrelin whose sequence is identical to ghrelin except for one glutamine in position 14 (Hosoda et al. 2000a). Both peptides have GH-releasing properties in vivo (Hosoda et al. 2000a). As well as stomach, it was recently reported that ghrelin is expressed in human and rat placenta (Gualillo et al. 2001). So far the physiological role of ghrelin is poorly understood but a role in the regulation of metabolic balance has been suggested (Tschöp et al. 2000). However, it was recently reported that a single injection of ghrelin to healthy volunteers had rapid cardiovascular effects including decreased blood pressure, increased stroke volume and increased cardiac output (Nagaya et al. 2001a). Moreover, administration of ghrelin to rats with experimental myocardial infarction improved systolic function (Nagaya et al. 2001b). Since ghrelin administration in this last study also elicited a potent increase in circulating GH and IGF-I levels, it is not clear whether the effects of ghrelin were direct on cardiovascular tissue or mediated by GH. The finding in the present study that ghrelin stimulates thymidine incorporation in H9c2 cells suggests potential effects on the cardiovascular system which merit further investigation.
Although our findings demonstrate direct effects of peptide GHS on thymidine incorporation, it should be pointed out that it is not possible to directly compare these effects with previously reported cardioprotective effects in vivo and further studies directed at intracellular signaling and anti-apoptotic effects are needed to clarify this issue.

Several studies have addressed the binding of GHS to specific receptors in the cardiovascular system. Using ${ }^{125}$ I-labeled Tyr-Bpa-Ala-hexarelin, a photoactivatable derivative of hexarelin, Ong and collaborators were able to demonstrate in competitive binding studies that hexarelin, MK-0677 (Ong et al. 1998b, Bodart et al. 1999) and EP51389 (Bodart et al. 1999) had very different binding patterns. Hexarelin could completely displace the radioligand in heart membranes, although it showed a lower affinity than in the pituitary. EP51389 and MK-0677 showed no displacement at the concentrations used. The results in the present study confirm specific binding of iodinated Tyr-Ala-hexarelin with complete displacement with hexarelin, Tyr-Ala-hexarelin and to a lesser extent ghrelin. The neuropeptide SRIF-14, which has a known negative effect on $\mathrm{GH}$ release, did not show any displacing effect. MK-0677 and EP51389 were not as potent in displacing Tyr-Ala-hexarelin at comparable concentrations. Together with the finding that H9c2 cells do not express the GHS-R1a receptor demonstrated with RTPCR, this would add further support for an alternative subtype binding site in the heart compared with the pituitary.

There are several advantages in using the H9c2 cell line and it has been shown that H9c2 cells express specific cardiac markers. Hescheler et al. (1991) characterized the $\mathrm{H} 9 \mathrm{c} 2$ cells as immature embryonic cardiomyocytes with electrical and hormonal signal pathways preserved as in adult cardiac cells. They also reported that $95 \%$ of $\mathrm{H} 9 \mathrm{c} 2$ cells are mononucleated and that they express L-type calcium channels which are typical for cardiomyocytes. The L-type calcium channels were also found by Sipido \& Marban (1991), who also pointed out that H9c2 cells had been neglected as potential surrogates for primary cardiac cells. H9c2 cells also show expression of $\mathrm{N}$-cadherin, a specific component of intercalated discs in cardiac muscle tissue (Wu et al. 1996). However, it should also be pointed out that the H9c2 cell line has both cardiomyocyte and skeletal muscle properties and seems to become more dedifferentiated over passages. Under the culturing conditions used in the present paper, with exponentially dividing cells, we could not detect any myoblast fusion, which would indicate differentiation towards a more skeletal muscle cell-like phenotype. Another rationale for using $\mathrm{H} 9 \mathrm{c} 2$ cells is that they express specific surface receptors for IGF-I, which has been shown to stimulate H9c2 cell proliferation (Chen et al. 1995, Bahr et al. 1997) and inhibit apoptosis (Wang et al. 1998). This would be an advantage when choosing H9c2 as a cardiomyocyte cell line to investigate stimulatory effects of endocrine factors. 
Nevertheless, even if $\mathrm{H} 9 \mathrm{c} 2$ cells have many cardiomyocyte-like properties, one should bear in mind that the GHRP binding properties of this cell type may to some extent differ from adult rat cardiac tissue.

In conclusion, accumulating data suggest a number of GH-independent effects of synthetic GHRPs and ghrelin on the cardiovascular system, also at the cellular level on cardiomyocytes and vascular smooth muscle cells. However, very little is known about mechanisms of action of these potential cardiovascular therapeutic agents and further studies are clearly warranted to clarify this.

\section{Acknowledgements}

The present study was supported by the Swedish Medical Research Council (12581), the Swedish Heart and Lung Foundation (41229) and Europeptides, Argenteuil, France. The authors are grateful to Marion Walser for excellent technical assistance.

\section{References}

Ariyasu H, Takaya K, Tagami T, Ogawa Y, Hosoda K, Akamizu T, Suda M, Koh T, Natsui K, Toyooka S, Shirakami G, Usui T, Shimatsu A, Doi K, Hosoda H, Kojima M, Kangawa K \& Nakao K 2001 Stomach is the major source of circulating ghrelin, and feeding state determines plasma ghrelin-like immunoreactivity levels in humans. Journal of Clinical Endocrinology and Metabolism $\mathbf{8 6}$ 4753-4758.

Bahr M, Kolter T, Seipke G \& Eckel J 1997 Growth promoting and metabolic activity of the human insulin analogue [GlyA21, ArgB31, ArgB32] insulin (HOE 901) in muscle cells. European Journal of Pharmacology 320 259-265.

Bisi G, Podio V, Valetto MR, Broglio F, Bertuccio G, Aimaretti G, Pelosi E, Del Rio G, Giampiero M, Ong H, Boghen MF, Deghenghi R \& Ghigo E 1999 Cardiac effects of hexarelin in hypopituitary adults. European Journal of Pharmacology 381 31-38.

Bodart V, Bouchard JF, McNicoll N, Escher E, Carrière, Ghigo E, Sejlitz T, Sirois MG, Lamontagne D \& Ong H 1999 Identification and characterization of a new growth hormone-releasing peptide receptor in the heart. Circulation Research 85 796-802.

Bodart V, Febbraio M, Demers A, McNicoll N, Pohankova P, Perreault A, Sejlitz T, Escher E, Silverstein RL, Lamontagne D \& Ong H 2002 CD36 mediates the cardiovascular action of growth hormone-releasing peptides in the heart. Circulation Research 90 844-849.

Bowers CY 1998 Growth hormone-releasing peptide (GHRP). Cellular and Molecular Life Sciences 54 1316-1329.

Bowers CY, Momany FA, Reynolds GA \& Hong A 1984 On the in vitro and in vivo activity of a new synthetic hexapeptide that acts on the pituitary to specifically release growth hormone. Endocrinology 114 1537-1545.

Camanni F, Ghigo E \& Arvat E 1998 Growth hormone-releasing peptides and their analogs. Frontiers in Neuroendocrinology 19 47-72.

Cassoni P, Papotti M, Catapano F, Ghè C, Deghenghi R, Ghigo E \& Muccioli G 2000 Specific binding sites for synthetic growth hormone secretagogues in non-tumoral and neoplastic human thyroid tissue. Journal of Endocrinology 165 139-146.

Chen QM, Tu VC, Wu Y \& Bahl JJ 2000 Hydrogen peroxide dose dependent induction of cell death or hypertrophy in cardiomyocytes. Archives of Biochemistry and Biophysics 373 242-248.
Chen WH, Pellegata NS \& Wang PH 1995 Coordinated effects of insulin-like growth factor-I on inhibitory pathways of cell cycle progression in cultured cardiac muscle cells. Endocrinology 136 $5240-5243$.

Chomzynski P \& Sacchi N 1987 Single step method of RNA isolation by acid guanidinium thiocyanate-phenol-chloroform extraction. Analytical Biochemistry 162 156-159.

De Gennaro Colonna V, Rossoni G, Bernareggi M, Müller EE \& Berti F 1997 Cardiac ischemia and impairment of vascular endothelium function in hearts from growth hormone-deficient rats: protection by hexarelin. European Journal of Pharmacology 334 201-207.

Deghenghi R, Cananzi MM, Torsello A, Battisti C, Müller EE \& Locatelli V 1994 GH-releasing activity of hexarelin, a new growth hormone releasing peptide, in infant and adult rats. Life Sciences $\mathbf{5 4}$ 1321-1328 [published erratum appears in Life Sciences $\mathbf{5 5}$ 1309-1309].

Dickson SL, Leng G \& Robinson ICAF 1993 Systemic administration of growth hormone-releasing peptide activates hypothalamic arcuate neurons. Neuroscience 53 303-306.

Filigheddu N, Fubini A, Baldanzi G, Cutrupi S, Ghé C, Catapano F, Broglio F, Bosia A, Papotti M, Muccioloi G, Ghigo E, Deghenghi R \& Graziani A 2001 Hexarelin protects H9c2 cardiomyocytes from doxorubicin-induced cell death. Endocrine 14 113-119.

Ghigo E, Arvat E, Gianotti L, Imbimbo BP, Lenaerts V, Deghenghi R \& Camanni F 1994 Growth hormone-releasing activity of hexarelin, a new synthetic hexapeptide, after intravenous, subcutaneous, intranasal, and oral administration in man. Journal of Clinical Endocrinology and Metabolism 78 693-698.

Gualillo O, Caminos J, Blanco M, Garcia-Caballero T, Kojima M, Kangawa K, Dieguez C \& Casanueva F 2001 Ghrelin, a novel placental-derived hormone. Endocrinology 142 788-794.

Hescheler J, Meyer R, Plant S, Krautwurst D, Rosenthal W \& Schultz G 1991 Morphological, biochemical, and electrophysiological characterization of a clonal cell $(\mathrm{H} 9 \mathrm{c} 2)$ line from rat heart. Circulation Research 69 1476-1486.

Hosoda H, Kojima M, Matsuo H \& Kangawa K 2000a Purification and characterization of rat des-Gln14-ghrelin, a second endogenous ligand for the growth hormone secretagogue receptor. Journal of Biological Chemistry 275 21995-22000.

Hosoda H, Kojima M, Matsuo H \& Kangawa K 2000 b Ghrelin and des-acyl ghrelin: two major forms of rat ghrelin peptide in gastrointestinal tissue. Biochemical and Biophysical Research Communications 279 909-913.

Howard AD, Feighner SD, Cully DF, Arena JP, Liberator PA, Rosenblum CI, Hamelin M, Hreniuk DL, Palyha OC, Anderson J, Paress PS, Diaz C, Chou M, Liu KK, McKee KK, Pong SS, Chaung LY, Elbrecht A, Dashkevicz M, Heavens R, Rigby M, Sirinathsinghji DJ, Dean DC, Melillo DG \& Van der Ploeg LHT 1996 A receptor in pituitary and hypothalamus that functions in growth hormone release. Science 273 974-977.

Kimes BW \& Brandt BL 1976 Properties of a clonal muscle cell line from rat heart. Experimental Cell Research 98 367-381.

Kojima M, Hosoda H, Data Y, Nakazato M, Matsuo H \& Kangawa K 1999 Ghrelin is a growth hormone-releasing acylated peptide from stomach. Nature 402 656-660.

Locatelli V, Rossoni G, Schweiger F, Torsello A, De Gennaro Colonna V, Bernareggi M, Deghenghi R, Müller EE \& Berti $F$ 1999 Growth hormone-independent cardioprotective effects of hexarelin in the rat. Endocrinology 140 4024-4031.

McKee KK, Palyha OC, Feigner SD, Hreniuk DL, Tan CP, Phillips MS, Smith RG, Van Der Ploeg LHT \& Howard AD 1997a Molecular analysis of rat pituitary and hypothalamic growth hormone secretagogue receptors. Molecular Endocrinology 11 415-423.

McKee KK, Tan CP, Palyha OC, Liu J, Feighner SD, Hreniuk DL, Smith RG, Howard AD \& Van der Ploeg LHT $1997 b$ Cloning and 
characterization of two human $G$ protein-coupled receptor genes (GPR38 and GPR39) related to the growth hormone secretagogue and neurotensin receptor. Genomics 46 426-434.

Momany FA, Bowers CY, Reynolds GA, Chang D, Hong A \& Newlander K 1981 Design, synthesis, and biological activity of peptides which release growth hormone in vitro. Endocrinology 108 31-39.

Muccioli G, Ghe C, Ghigo MC, Papotti M, Arvat E, Boghen MF, Nilsson MH, Deghenghi R, Ong H \& Ghigo E 1998 Specific receptors for synthetic $\mathrm{GH}$ secretagogues in the human brain and pituitary gland. Journal of Endocrinology 157 99-106.

Muccioli G, Papotti M, Locatelli V, Ghigo E \& Deghenghi R 2001 Binding of ${ }^{125} \mathrm{I}$-labeled ghrelin to membranes from human hypothalamus and pituitary gland. Journal of Endocrinological Investigations 24 RC7-RC9.

Nagaya N, Kojima M, Uematsu M, Yamagishi M, Hosoda H, Oya H, Hayashi Y \& Kangawa K 2001a Hemodynamic and hormonal effects of human ghrelin in healthy volunteers. American Journal of Physiology Regulatory, Integrative and Comparative Physiology 280 R1483-R1487.

Nagaya N, Uematsu M, Kojima M, Ikeda Y, Yoshihara F, Shimizu W, Hosoda H, Hirota Y, Ishida H, Mori H \& Kangawa K 2001 b Chronic administration of ghrelin improves left ventricular dysfunction and attenuates development of cardiac cachexia in rats with heart failure. Circulation 104 1430-1435.

Ong H, McNicoll N, Escher E, Collu R, Deghenghi R, Locatelli V, Ghigo E, Muccioli G, Boghen M \& Nilsson M 1998a Identification of a pituitary growth hormone-releasing peptide (GHRP) receptor subtype by photoaffinity labeling. Endocrinology 139 432-435.

Ong H, Bodart V, McNicoll N, Lamontagne D \& Bouchard JF 19986 Binding sites for growth hormone-releasing peptide. Growth Hormone and IGF Research 8 (Suppl B) 137-140.

Palyha OC, Feighner SD, Tan CP, McKee KK, Hreniuk DL, Gao YD, Schleim KD, Yang L, Morriello GJ, Nargund R, Patchett AA, Howard AD \& Smith RG 2000 Ligand activation domain of human orphan growth hormone $(\mathrm{GH})$ secretagogue receptor (GHS-R) conserved from pufferfish to humans. Molecular Endocrinology 14 160-169.

Papotti M, Ghè C, Cassoni P, Catapano F, Deghenghi R, Ghigo E \& Muccioli G 2000 Growth hormone secretagogues binding sites in peripheral human tissues. Journal of Clinical Endocrinology and Metabolism 85 3803-3807.

Pong SS, Chaung LY, Dean DC, Nargund RP, Patchett AA \& Smith RG 1996 Identification of a new G-protein-linked receptor for growth hormone secretagogues. Molecular Endocrinology 10 57-61.
Rossoni G, De Gennaro Colonna V, Bernareggi M, Polvani GL, Müller EE \& Berti F 1998 Protectant activity of hexarelin or growth hormone against postischemic ventricular dysfunction in hearts from aged rats. Journal of Cardiovascular Pharmacology 32 260-265.

Shimon I, Yan X \& Melmed S 1998 Human fetal pituitary expresses functional growth hormone-releasing peptide receptors. Journal of Clinical Endocrinology and Metabolism 83 174-178.

Sipido KR \& Marban E 1991 L-type calcium channels, potassium channels, and novel nonspecific cation channels in a clonal muscle cell line derived from embryonic rat ventricle. Circulation Research 69 1487-1499.

Smith RG, Van der Ploeg LH, Howard AD, Feighner SD, Cheng K, Hickey GJ, Wyvratt MJ Jr, Fisher MH, Nargund RP \& Patchett AA 1997 Peptidomimetic regulation of growth hormone secretion. Endocrine Reviews 18 621-645.

Tan CP, McKee KK, Liu Q, Palyha OC, Feighner SD, Hreniuk DL, Smith RG \& Howard AD 1998 Cloning and characterization of a human and murine T-cell orphan G-protein-coupled receptor similar to the growth hormone secretagogue and neurotensin receptors. Genomics $\mathbf{5 2} 223-229$.

Tivesten Å, Bollano E, Caidahl K, Kujacic V, Sun XY, Hedner T, Hjalmarson Å, Bengtsson B-Å \& Isgaard J 2000 The growth hormone secretagogue hexarelin improves cardiac function in rats after experimental myocardial infarction. Endocrinology 141 60-66.

Tschöp M, David L, Heiman S \& Heiman ML 2000 Ghrelin induces adiposity in rodents. Nature 407 908-913.

Wang L, Ma W, Markowich R, Lee W-L \& Wang PH 1998 Insulin-like growth factor I modulate induction of apoptotic signalling in $\mathrm{H} 9 \mathrm{c} 2$ cardiac muscle cells. Endocrinology 139 1354-1360.

Wu ML, Tsai KL, Wang SM, Wu JC, Wang BS \& Lee YT 1996 Mechanism of hydrogen peroxide and hydroxyl free radical-induced intracellular acidification in cultured rat cardiac myoblasts. Circulation Research 78 564-572.

Yokote R, Sato M, Matsubara S, Ohye H, Niimi M, Murao K \& Takahara J 1998 Molecular cloning and gene expression of growth hormone-releasing peptide receptor in rat tissues. Peptides 19 15-20.

Received in final form 7 June 2002

Accepted 12 June 2002 